\title{
Sindicalismo e trabalho ferroviário em São Paulo: a Companhia Paulista de Estradas de Ferro entre o início do século XX e sua estatização *
}

\author{
Guilherme Grandi ** \\ Ivanil Nunes ${ }^{* * *}$
}

\begin{abstract}
Resumo
O objetivo deste artigo é analisar historicamente a expansão da atividade sindical dos ferroviários no processo que culminou na estatização da Companhia Paulista de Estradas de Ferro. Ao longo dos anos 1950, o sistema ferroviário brasileiro passou por uma profunda mudança de cunho estatizante que se estendeu até a década de 1990. Todas as grandes companhias nacionais já haviam sido estatizadas, exceto a Paulista, que seguiu privada até 1961. Em um contexto de liberdade sindical (de 1946 a 1964), os trabalhadores retomaram sua histórica luta por melhores condições de trabalho e aumentos salariais, ao mesmo tempo em que a Paulista enfrentava a acirrada concorrência intermodal e a inexorável redução do seu saldo operacional. Será que a exacerbação do conflito entre capital e trabalho teria contribuído, em termos decisivos, para a estatização da Paulista? Os argumentos que apresentamos sugerem que a inflação e a luta por equiparação salarial foram os principais elementos que levaram à sublevação dos ferroviários e, portanto, contribuíram para o processo de estatização da Companhia.
\end{abstract}

Palavras-chave: Sindicalismo; Trabalho ferroviário; Estatização; Companhia Paulista; Ferrovias.

\begin{abstract}
Unionism and railway work in São Paulo: The Paulista Railway Company from the beginning of the twentieth century to its nationalization

The aim of this paper is to historically analyze the expansion of the railway trade union activity during the process that culminated in the nationalization of the Paulista Railway Company. Throughout the 1950s, the Brazilian railway system underwent a change towards greater state control that lasted until the 1990s. All major national companies had already been nationalized, with the exception of the Paulista Company, which remained private until 1961. In this context of union freedom (from 1946 to 1964), workers resumed their historical struggle for better working conditions and wage increases, while Paulista faced fierce intermodal competition and a relentless reduction in its operational balance. Could the exacerbation of the conflict between capital and labor have contributed, in definitive terms, to the nationalization of the Paulista Railway Company? We present arguments that suggest that inflation and the struggle for wage equalization were the main factors that led to the uprising of the railway workers and, therefore, contributed to the company's nationalization process.
\end{abstract}

Key words: Unionism; Railway work; Nationalization: Paulista Company; Railways.

JEL N76, N86, J59.

\footnotetext{
*Artigo recebido em 23 de novembro de 2017 e aprovado em 20 de abril de 2018.

${ }^{* *}$ Professor doutor do Departamento de Economia da Faculdade de Economia, Administração e Contabilidade da Universidade de São Paulo (FEA/USP), São Paulo, SP, Brasil. E-mail: ggrandi@usp.br.

*** Professor da Escola Paulista de Política, Economia e Negócios da Universidade Federal de São Paulo (EPPEN/Unifesp), Osasco, SP, Brasil. E-mail: profivanilnunes@gmail.com.
} 


\section{Introdução}

Desde a aprovação dos seus estatutos, pelo Decreto Imperial n. 4.283 de 28 de novembro de 1869, até a desapropriação de suas ações pelo governo do estado de São Paulo, em $1^{\circ}$ de junho de 1961 (Decreto 38.548), a Companhia Paulista de Estradas de Ferro passou por diversas fases de sua trajetória como empresa privada nacional de capital aberto e marcou, em termos decisivos, a história econômica e social da província e do estado de São Paulo, pois ela foi por décadas o benchmark das companhias que constituíram a rede de transporte sobre trilhos no Brasil. Conhecida pela regularidade dos seus trens e vista como sinônimo de eficiência econômica e equilíbrio financeiro, a Paulista é um dos poucos casos de sucesso empresarial de longa duração por conseguir manter-se superavitária durante toda sua existência até às vésperas de sua estatização.

A partir dos anos 1950, no entanto, dá-se o surgimento de diversos fatores concorrentes ao bom desempenho econômico e financeiro da Companhia. Dentre esses fatores, destaca-se a exacerbação do conflito entre capital e trabalho ocorrida em meio a um cenário de crise dos meios de transporte, de alta inflacionária e de um setor ferroviário já quase todo estatizado. $\mathrm{O}$ embate entre a diretoria da Paulista e o sindicato que representava seus ferroviários levou ao fim a gestão privada da última companhia ferroviária que restava ao país estatizar.

É possível identificar duas vertentes interpretativas sobre a constituição dos sindicatos no Brasil. Por um lado, alguns autores sustentam que uma das principais características das organizações sindicais do país é sua fraqueza, ou inconsistência, política e social. Originária do próprio processo de formação da classe trabalhadora brasileira, tal fragilidade se expressaria pela reduzida capacidade organizativa dos sindicatos diante do patronato e do poder estatal com respeito às questões relativas aos conflitos de trabalho. Segundo Rodrigues (1974), além da ausência de autonomia, faltaria aos trabalhadores brasileiros a capacidade de formar partidos de massa visando o enfrentamento ideológico com o empresariado. Por outro lado, as três primeiras décadas do século XX testemunharam expressivas mobilizações de trabalhadores em um contexto institucional marcado pela total inexistência de um sistema de proteção social ao trabalhador (Costa, 1986). A estrutura sindical urdida a partir dos anos 1930, submetida às Federações e Confederações sindicais e à Justiça do Trabalho, assinala um momento no qual o Estado cria mecanismos institucionais com o intuito de controlar a atividade sindical (Boito Jr., 1991, p. 26).

No imediato pós-1930, portanto, o Estado não agiu de forma neutra, isto é, acima dos interesses que estavam em jogo naquela conjuntura, mas se inclinou a satisfazer a demanda dos grupos industriais por meio de sua prerrogativa de reorganizar o mercado de trabalho nacional. Até a aprovação da lei que passou a regular a sindicalização das classes patronais e trabalhadoras de $1931^{1}$, as reivindicações dos ferroviários, bem como o próprio sentido da

(1) Decreto 19.770 de 19 de março de 1931. "Em primeiro lugar, definia o sindicato como órgão consultivo e de colaboração do poder público, ou seja, trazia o sindicato para a órbita do Estado, considerando-o, embora indiretamente, parte do aparato governamental. Os sindicatos, pela lei, teriam que ser oficialmente reconhecidos pelo Ministério do Trabalho, para o que 
causa operária em São Paulo, estavam eivadas por ideologias de nuanças diversas, como o anarquismo, o socialismo e o anarcossindicalismo. A estratégia de ação política se efetuava, sobretudo, por meio de greves organizadas em torno da mobilização das classes trabalhadoras e através de comícios em espaços públicos. Grande parte desses atos tinha o apoio dos sindicatos que representavam as categorias mais antigas e numerosas de trabalhadores urbanos, a exemplo dos ferroviários. Decerto, estes, particularmente os trabalhadores da Companhia Paulista, detêm um papel de destaque com respeito à trajetória do movimento operário e sindical de São Paulo, em função de terem sido uma das primeiras categorias a se organizar no combate à exploração e na luta por melhores condições de trabalho.

Diante desses fatos e especificidades históricas, nosso objetivo é examinar a expansão e a relação da atividade sindical dos ferroviários no processo que culminou na estatização da Companhia Paulista de Estradas de Ferro. Com exceção da Paulista, quase todas as grandes companhias de estradas de ferro já haviam sido estatizadas até o final da década de $1950^{2}$. Em um contexto de liberdade sindical, entre 1946 e 1964, os trabalhadores retomaram sua luta por melhores condições de trabalho e aumentos salariais, ao mesmo tempo em que as ferrovias, especialmente as de São Paulo, enfrentavam a acirrada concorrência intermodal e a inexorável redução de seus saldos operacionais. Nesse passo, cabe indagarmos se a exacerbação do conflito entre capital e trabalho, bem como a atuação do Sindicato dos Trabalhadores em Empresas Ferroviárias da Zona Paulista, teriam contribuído, em termos decisivos, para a estatização da última companhia ferroviária privada existente no país do período anterior ao golpe militar de 1964.

era necessário o cumprimento de uma série de exigências, como a apresentação de sus relação de sócios, estatuto e atas dos trabalhos de instalação. Permaneceriam também sob permanente fiscalização dos agentes do Ministério que possuíam o direito de assistir a suas assembleias, intervir em suas deliberações e até investigar sua contabilidade. Além disso, era expressamente vedada aos sindicatos a propaganda de ideologias políticas e religiosas" (Gomes, 2014, p. 280).

(2) A maior evidência histórica da política nacional de estatização do setor ferroviário foi a formação da própria Rede Ferroviária Federal S.A. (RFFSA) em 1957. Tal política resultou de um amplo processo de concentração de empresas do setor e esteve amparada pelas seguintes leis federais: Lei no 1.746, de 28 de novembro de 1952; Lei no 2.145, de 29 de dezembro de 1953; e, fundamentalmente, a Lei no 2.698, de 27 de dezembro de 1955. Esta última dispunha sobre a forma de aplicar a receita proveniente da diferença de preços entre os combustíveis e lubrificantes líquidos, derivados do petróleo, fabricados dentro e fora do Brasil e em seu Art. 9o (§ $\left.5^{\circ}\right)$ lê-se: "O produto da arrecadação de $30 \%$ (trinta por cento), previsto no inciso II do $\S 2^{\circ}$ dêste artigo, será diretamente recolhido pelo Banco do Brasil, ao Banco Nacional do Desenvolvimento Econômico para aplicação na pavimentação de rodovias e na construção, revestimento ou pavimentação de rodovias destinadas a substituir ramais ferroviários reconhecidamente deficitários". Portanto, o propósito de estatizar a malha ferroviária nacional se deu de modo intrinsecamente vinculado ao principal objetivo dessa política federal, qual seja, o da constituição do Fundo Nacional de Pavimentação e do Fundo Especial. As obras de construção, revestimento ou pavimentação das estradas de rodagem seriam elaboradas, de acordo com a Lei 2.698, pelo Departamento Nacional de Estradas de Rodagem (DNER), mediante a indicação do Departamento Nacional de Estradas de Ferro (DNEF) e com audiência das secretarias estaduais competentes, para os casos em que a linha férrea a ser suprimida pertencer aos governos dos estados. Segundo o parágrafo segundo do Art. 6o da mesma lei, “A prioridade para seleção dêsses projetos será a menor densidade de tráfego ferroviário remunerado, computada em toneladas-quilômetros de linha explorada $(\mathrm{t}-\mathrm{km} / \mathrm{km})$, dando-se preferência, em caso de valores semelhantes à linha que acusar a maior despesa de custeio anual por quilômetro de acôrdo com os dados relativos ao ano de 1952" (https://www2.camara.leg.br/legin/fed/lei/1950-1959/lei-2698-27dezembro-1955-355007-publicacaooriginal-1-pl.html). Em razão da referida Lei, a Companhia Paulista fez um levantamento dos trechos de sua rede ferroviária que deveriam ser erradicados a partir de 1960 (a esse respeito ver Grandi, 2013, p. 274). 
O presente artigo subdivide-se em três seções, além desta breve introdução e das considerações finais. Na primeira, apresentamos algumas considerações preliminares que julgamos importantes sobre a expansão tanto das linhas férreas quanto dos ferroviários no Brasil, além de discutirmos alguns traços do início do movimento de politização dos trabalhadores urbanos. Nessa primeira fase, jornais operários e a formação das chamadas ligas operárias tiveram um papel fundamental no processo de conscientização e organização política das diversas categorias de trabalhadores que resultou na conquista das primeiras leis sociais aprovadas no país. Na segunda seção, abordamos a atuação política de alguns dos sindicatos ferroviários de São Paulo no início dos anos 1930, período em que se observa um recrudescimento da violência policial praticada pelo Estado em seu esforço de coagir as sublevações trabalhistas que, do ponto de vista dos agentes do Departamento Estadual de Ordem Política e Social (DEOPS/SP), vinham sendo fortemente influenciadas pelas ideologias do socialismo e do comunismo. Por fim, na terceira seção, examinamos a conjuntura econômica dos anos 1950 e seu impacto sobre a relação capital-trabalho numa das ferrovias mais importantes do estado de São Paulo até sua estatização, ocorrida em 1961. Trata-se da já citada Companhia Paulista de Estradas de Ferro, doravante referenciada apenas como Paulista.

\section{Mão de obra ferroviária e legislação social no Brasil}

$\mathrm{O}$ advento das estradas de ferro acarretou mudanças significativas nas relações de trabalho no Brasil. A proibição legal da utilização de escravos, a necessidade de um grande contingente de mão de obra qualificada e semiqualificada, além da presença do trabalho imigrante nos diversos serviços de construção, operação e manutenção das ferrovias brasileiras fizeram parte do processo de transição do sistema escravista para o do trabalho livre e assalariado. Contudo, a trajetória dos ferroviários de São Paulo assumia características distintas das experiências do trabalho livre que se observa em outras regiões do Brasil. A propósito, Lamounier afirma que desde a construção das primeiras estradas de ferro, muitos trabalhadores provinham da agricultura de exportação e que, nos momentos da entressafra do plantio do café, se notava uma relativa abundância de mão de obra livre e nativa que acabava sendo empregada no trabalho ferroviário, pelo menos por um período determinado $(2000 \text {, p. } 21)^{3}$. Lanna, que trabalhou com os prontuários funcionais dos ferroviários da Paulista, esclarece também que a maior parte dos empregados da ferrovia era de trabalhadores nacionais. Logo, o argumento acerca da suposta qualificação superior da mão de obra imigrante, de origem estrangeira, não encontra base de sustentação empírica quando se investiga o caso do trabalho ferroviário realizado na Paulista (2016, p. 522) .

(3) Para um aprofundamento sobre o tema da construção de ferrovias no Brasil, ver Lamounier (2012).

(4) Em contrapartida, Versiani nota que desde os primeiros estágios do desenvolvimento industrial em São Paulo, as atividades que exigiam maiores níveis de qualificação eram, em sua maioria, exercidas pela mão de obra vinda do exterior, diferentemente do que ocorria no Rio de Janeiro, onde a presença de trabalhadores nacionais era mais significativa (1993, p. 82). No caso específico da Paulista, "Os trabalhadores de construção das linhas ou de sua manutenção são os de menor qualificação e, em geral, eram treinados e recrutados pelos próprios funcionários da Paulista. Eram organizados por turmas, controlados por feitores e sua condição de trabalho era instável e precária. De maneira distintas daqueles empregados nas oficinas, na condução das máquinas e na parte administrativa, tiveram sua vida funcional marcada por inúmeras interrupções definidas pelo ritmo das obras às quais estavam vinculadas" (Lanna, 2016, p. 534). 
Sindicalismo e trabalho ferroviário em São Paulo: a Companhia Paulista de Estradas de Ferro entre o início do século XX e sua estatização

Em São Paulo, polo dinâmico da cafeicultura, pelo menos nove ferrovias foram construídas entre as décadas de 1880 e o início de 1890: E.F. do Bananal, Companhia Rio Claro, Companhia Ramal Férreo do Rio Pardo, Companhia Itatibense, Companhia Agrícola Fazenda Dumont, Companhia Descalvadense, Companhia Ramal Férreo de Santa Rita, Companhia Ramal Férreo Campineiro e Companhia Carril Agrícola Funilense. Em virtude dessa expansão, ao menos 33.191 ferroviários compunham o conjunto da categoria em dezembro de 1906; dez anos depois, tal quantidade se ampliou para um total de 57.912 ferroviários no país, o que representa um aumento de 74,5\% (Brasil, MVOP, 1922, p. 115$119)$, num momento em que a extensão da rede nacional de estradas de ferro havia crescido 56,6\%, aumentando de 17.242 para 27.014 quilômetros (Brasil, MVOP, 1955, p. 47).

Tabela 1

Quantidade de ferroviários, 1906 e 1916 (companhias selecionadas)

\begin{tabular}{l|c|c|c|c}
\hline Estrada de Ferro & 1906 & 1916 & Variação \% & Estado \\
\hline Central do Brasil & 11.528 & 17.038 & 47,8 & RJ \\
\hline Santos-Jundiaí & 4.424 & 6.110 & 38,1 & SP \\
\hline Great Western & 2.735 & 5.227 & 91,1 & RN-PE-AL-BA \\
\hline V. F. Rio Grande do Sul & 1.836 & 3.698 & 101,4 & RS \\
\hline Companhia Paulista & 1.755 & 4.049 & 130,7 & SP \\
\hline E. F. Oeste de Minas & 1.370 & 2.180 & 59,1 & MG \\
\hline Companhia Mogiana & 1.179 & 868 & $-26,4$ & SP \\
\hline E. F. São Paulo-Rio Grande & 458 & 2.444 & 433,6 & SP-PR-SC-RS \\
\hline E. F. Recife a Limoeiro & 225 & 843 & 274,7 & PE \\
\hline E. F. Noroeste & 125 & 727 & 481,6 & SP-MS \\
\hline
\end{tabular}

Fonte: Brasil. MVOP (1908, p. 51-52); Idem (1922, p. 115-119)

Embora a Companhia Central do Brasil concentrasse cerca de 30\% dos ferroviários brasileiros em 1916, o ritmo de aumento da mão de obra foi muito maior em outras empresas do setor, como na Noroeste, na São Paulo-Rio Grande, na Recife a Limoeiro e Timbaúba e na própria Paulista. Das dez companhias acima elencadas, sete empregavam mais de 2.000 empregados em 1916 e as quinze maiores empresas reuniam aproximadamente $88 \%$ da mão de obra ferroviária do país. Pelo menos dois fatores principais contribuíram para o aumento da oferta de ferroviários ao longo dos dois primeiros decênios do século XX: a própria expansão das linhas férreas por todo território nacional e o modelo de negócio do setor ferroviário que obrigava as companhias a transportar todo e qualquer tipo de mercadoria que fosse despachado pelos clientes em suas estações de embarque, o que, por sua vez, aumentava a demanda por mão de obra. A quantidade de ferroviários que havia crescido de modo proporcional à expansão das linhas férreas entre 1905 e 1913, começou a aumentar mais rapidamente a partir de 19131918 e seguiu aumentando proporcionalmente mais do que a ampliação do sistema ferroviário nos anos subsequentes, a ponto do Brasil superar a marca de 70.000 ferroviários em 1920. A figura a seguir, ilustra a trajetória da curva que representa o aumento da quilometragem 
ferroviária em comparação ao da expansão da mão de obra empregada nas companhias de estrada de ferro.

Figura 1

Brasil: relação entre a expansão das linhas férreas e da mão de obra, $1905-1940(1905=100)$

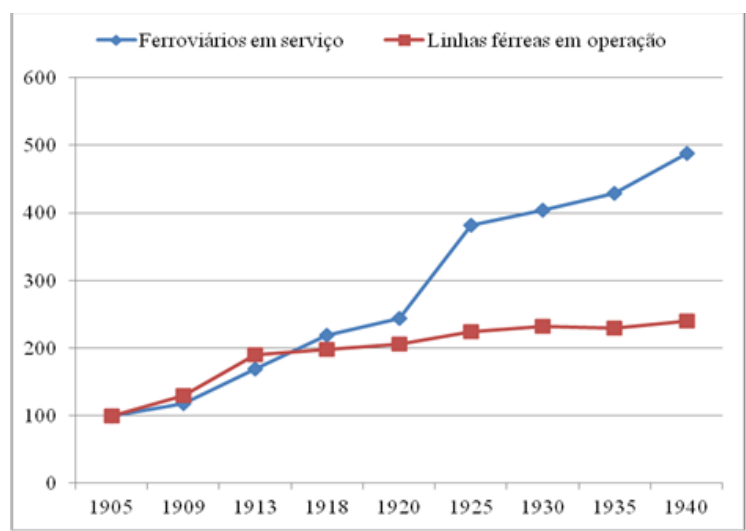

Fonte: Brasil, MVOP, anos diversos.

As primeiras organizações formais de trabalhadores, embora influenciadas pela presença sociocultural dos imigrantes europeus, foram se constituindo a partir de um processo de reinvenção adaptativa à realidade brasileira. No caso específico dos ferroviários paulistas, os primeiros esforços organizativos remontam à passagem do século XIX para o XX e estão documentados em alguns dos principais jornais operários que circulavam entre as estações e as composições ferroviárias por meio da atividade das chamadas ligas operárias. A maioria desses jornais operários, que datam do período anterior à Primeira Guerra, provinha das cidades de São Paulo e do Rio de Janeiro e possuía um viés editorial de influências fortemente anarquistas, socialistas ou anarcossindicalist ${ }^{5}$. Em alguns casos, seus editores se manifestavam explicitamente a favor da sindicalização de todos os trabalhadores independentemente da origem étnica. Em 1909, por exemplo, um desses jornais noticiou, com grande entusiasmo, que os sindicatos da construção civil de Santos "haviam forçado os empreiteiros a admitir somente pessoal sindicalizado” (A Voz do Trabalhador, 1/6/1909). Já outro periódico insistia na ideia de que o trabalhador sindicalizado absorvia mais facilmente a propaganda anarquista e, assim, conseguiria compreender melhor a origem de seus problemas ao ficar moral e materialmente

(5) “O anarquismo e o socialismo foram as ideologias predominantes no movimento sindical até por volta de 1925. Daí por diante aquele predomínio foi dividido com o partido comunista que se formara entre 1919 e 1923. A Federação operária de influência anarquista, foi fechada em 1934 e a ditadura implantada a partir de 1935 expulsou dos sindicatos os militantes anarquistas, comunistas e socialistas. Com a redemocratização do país, após a última guerra, os comunistas passaram a ser os maiores dinamizadores da organização sindical (e isto eu afirmo imparcialmente, pois sempre fui membro do partido socialista)" (Simão, 2012, p. 291). 
Sindicalismo e trabalho ferroviário em São Paulo: a Companhia Paulista de Estradas de Ferro entre o início do século XX e sua estatização

preparado para conhecer a conclusão lógica do movimento sindicalista: "a expropriação revolucionária da terra e de todos os meios de produção" (A Terra Livre, 11 nov. 1906).

Outro aspecto importante dessa fase inicial do movimento operário paulista refere-se ao protagonismo das sociedades de auxílio mútuo que, grosso modo, inauguraram uma forma de agir coletiva dos trabalhadores empregados especialmente no setor fabril. Sabe-se, contudo, que esse fenômeno não se restringiu à São Paulo e ao Brasil, pois há evidências de que o mutualismo era a forma predominante de associação de trabalhadores em busca de seus direitos também em outros países da América Latina que se encontravam nas fases iniciais do movimento de industrialização de suas economias (Collier; Collier, 2002). No caso específico de São Paulo no despontar do século XX, as sociedades de socorro mútuo formadas por imigrantes italianos eram majoritárias frente àquelas formadas por outros grupos étnicos de trabalhadores (Biondi, 2011).

Ao considerarmos um movimento grevista em particular, a greve dos ferroviários da Paulista de 1906, podemos sustentar que uma das conquistas daí resultante foi a legalização, no ano seguinte ao da greve, dos sindicatos de trabalhadores da indústria e do comércio, além da regulamentação da jornada de trabalho de oito horas, que passou a ser adotada por algumas indústrias e pelas principais companhias ferroviárias do estado de São Paulo, como a Mogiana e a própria Paulista (Grandi, 2014, p. 182). A legislação social mais abrangente também foi uma consequência direta dos movimentos sociais que lutavam por melhores condições de trabalho, bem como por um sistema de seguridade social que garantisse o emprego. Há evidências de que os ferroviários paulistas foram os primeiros trabalhadores a verem transformadas essas suas reivindicações em direitos.

A esse respeito, vale destacarmos o caso da Lei Elói Chaves, sancionada pelo Congresso Nacional através do Decreto n. 4.682 de 24 de janeiro de 1923. Essa lei refere-se à aprovação da Caixa de Aposentadoria e Pensões dos ferroviários do estado de São Paulo; uma lei responsável por lançar as bases sob as quais se apoiaria a legislação federal posterior. Também em 1923, aprovou-se o Decreto n. 16.027 de 30 de abril, que criou o Conselho Nacional do Trabalho, órgão consultivo dos poderes públicos em matérias relacionadas à organização do trabalho e à previdência social. Em seguida, viria a lei de férias (Decreto $\mathrm{n}$. 4.982, de 24 de dezembro de 1925), que concedia quinze dias de férias por ano aos empregados de estabelecimentos comerciais, industriais e bancários. Sua regulamentação, contudo, se daria posteriormente em 30 de outubro de 1926, pelo Decreto n. 17.496 (Silva, 1954, p. 85).

Logo após o término do que podemos chamar de primeira fase do movimento operário em São Paulo, teve início a institucionalização das leis trabalhistas no país em decorrência de duas décadas fortemente marcadas por greves, violência policial, esforço organizativo da liderança sindical e intensa militância por parte dos trabalhadores de determinados segmentos industriais. Nessa primeira fase, as categorias profissionais mais ativas e organizadas e que, portanto, congregavam o maior número de militantes eram os gráficos, chapeleiros, sapateiros, metalúrgicos, alfaiates, ferroviários, estivadores, calafates, mecânicos, tecelões e operários da 
construção civil. Foram estas categorias que se envolveram mais ativamente em greves e no movimento mais amplo que organizou o operariado industrial em sua luta política por condições mais dignas de trabalho, num ambiente caracterizado pela total ausência de uma legislação que garantisse direitos e assistência social ao trabalhador.

A isso, acrescentamos que não foram raros, durante esse período, casos de violência policial, prisões e até mortes de trabalhadores. Em 1907, no contexto da luta pela regulamentação da jornada de oito horas de trabalho, a Federação Operária de São Paulo (FOSP) repudiava a ação repressiva da polícia que, por sua vez, se justificava via imprensa dizendo estar tão somente cumprindo a lei.

Cumprir a lei é assaltar a sede de uma associação operária, confiscar papeis e documentos, prender e espancar operários, pacificamente reunidos, fechar o local da Federação Operária, no próprio dia em que a Comissão Executiva aconselhava serenidade e o não fornecimento de pretextos à polícia provocadora.

Cumprir a lei é prender operários por "crimes" como o de pretender dirigir-se a localidades onde há greves, como se tem dado com alguns companheiros!

Cumprir a lei é impedir o livre e público exercício do direito de reunião, ou pela violência direta ou pela pressão exercida sobre os proprietários de salões.

Cumprir a lei é burlar a magistratura judicial, quando ela pede informações sobre os presos em cujo favor foi requerido habeas-corpus; é mentir, dizendo que estão soltos, quando apenas os faz mudar de posto policial.

Oh, a lei não se cumpre, quando pode ser desfavorável aos patrões, aos que dispõem de dinheiro e de influência [...] (Avanti!', 24 maio 1907).

Passadas três décadas, parecia que o Estado brasileiro e o empresariado começavam a sinalizar uma mudança de postura ao reconhecerem determinados direitos, bem como a capacidade dos trabalhadores de se organizarem coletivamente. Se, por um lado, observava-se o início de um movimento de transformação institucional relacionado ao fator trabalho, através da garantia de determinados direitos, por outro, a violência policial não demostrava sinais de arrefecimento; pelo contrário, a mobilização sindical em torno da barganha coletiva de salários das diversas categorias de trabalhadores continuou sendo vista na sociedade brasileira como caso de polícia e, ao que tudo indica, nem mesmo após a aprovação da Consolidação das Leis do Trabalho (CLT), em 1943, essa questão deixou de figurar nos autos policiais do DEOPS.

\section{Os anos 1930 e a repressão aos "ferroviários comunistas" em São Paulo}

Durante a segunda metade dos anos 1920, as classes dominantes no Brasil se viram premidas em estabelecer uma nova correlação entre os interesses públicos e privados, uma vez que estava em jogo um movimento de regulamentação do Estado liberal associado a determinadas transformações experimentadas pela sociedade civil. Foi nesse momento que pela primeira vez na história do país os "donos do poder" se viram forçados a fazerem concessões aos trabalhadores que, desde as primeiras décadas do século, vinham reivindicando direitos políticos e sociais. $\mathrm{O}$ avanço em direção a uma legislação em prol dos trabalhadores 
Sindicalismo e trabalho ferroviário em São Paulo: a Companhia Paulista de Estradas de Ferro entre o início do século XX e sua estatização

não significava, contudo, um aperfeiçoamento do regime democrático no país, haja vista que a criação pelo Estado de um conjunto de leis trabalhistas tinha por propósito institucionalizar a questão social e, assim, controlar melhor o movimento sindical através de sua despolitização (Decca, 1992, p. 184-185).

Nos anos 1930, a repressão imposta pela polícia política já se voltava particularmente contra duas vertentes do movimento operário representadas pela atuação dos membros do Partido Comunista Brasileiro (PCB) e do Partido Socialista Brasileiro (PSB). A política de segurança pública do Estado havia se convencido de que qualquer agitação envolvendo piquetes em fábricas, reivindicações populares ou movimentos grevistas de trabalhadores tinha relação direta com a atuação dos comunistas que, filiados a um sindicato ou infiltrados no movimento sindical, exerciam forte influência sobre o operariado.

Alguns estudiosos têm trabalhado com a hipótese da existência de uma relação estreita entre os partidos de esquerda e o movimento sindical dos ferroviários. Brusantin (2003), por exemplo, sustenta que para a polícia política do primeiro governo Vargas havia uma inequívoca vinculação do Sindicato dos Ferroviários da Paulista com a Aliança Nacional Libertadora (ANL), o PSB e as demais organizações de esquerda. De fato, dentre os sindicatos de São Paulo oficialmente reconhecidos pelo Estado, os sindicatos ferroviários estavam entre os mais ativos e organizados do ponto de vista político. Consequentemente, as cidades paulistas que apresentavam um grau elevado de militância de trabalhadores eram, via de regra, importantes centros ferroviários como Jundiaí, Campinas, Rio Claro, São Carlos, Araraquara, Piracicaba, Barretos, Bauru, Araçatuba, Bebedouro, Sorocaba, Mogi-Mirim e Ribeirão Preto.

As articulações políticas de esquerda eram frequentemente descritas pela documentação policial como atos clandestinos, subversivos, malignos e causadores de desordem e que, portanto, suas práticas tinham sempre por objetivo desestabilizar o governo. O discurso policial estereotipava as atividades comunistas ao associá-las à imagem do "perigo oculto". Assim, a retórica presente nos relatórios do Deops constrói um ambiente de embate caricato no qual, de um lado, estavam a ordem, o progresso, a pátria e a família e, do outro, a desordem, a baderna, o "mal vermelho" e o anti-patriotismo.

As estratégias de luta por parte da resistência podem ser constatadas através da produção de boletins de propaganda comunista, intensa em todo o interior paulista. O discurso comunista não apenas combatia o integralismo como também incentivava os operários a participarem de reuniões sindicais, greves e comícios, além de lutarem contra o imperialismo e a burguesia. A maioria deste material sedicioso arquivado junto aos prontuários do DEOPS pertencia aos sindicatos ferroviários. Os boletins foram encontrados pela polícia nos trens das ferrovias paulistas, confirmando o modo pelo qual as ideias circulavam de forma a cumprir com seu objetivo imediato: informar de forma rápida e precisa, ainda que clandestina. Os propagandistas valiam por seu grau de inventividade e rapidez ao propagar a mensagem. Em São Carlos, na Zona Paulista, por exemplo, verificamos a circulação dos boletins $O$ Trilho e A Farpa. Em São Roque, Zona Sorocabana, o cidadão Itauty Carneiro de Magalhães, presidente do Sindicato da 
Sorocabana, foi apontado pela polícia como um dos “cabeças" do movimento ferroviário, principalmente por ser um grande produtor de boletins comunistas (Brusantin, 2003, p. 54-55).

O trecho acima nos remete a três elementos sociais que explicam sobremaneira a função histórica desempenhada pelas ferrovias e pelos ferroviários em relação à organização do movimento operário em São Paulo durante os anos 1930: primeiro, a interface existente entre a ideologia comunista e a atuação dos sindicatos ferroviários; segundo, o papel das ferrovias como propagadoras das mensagens e ideias de caráter comunista contidas nos boletins que circulavam por todo o interior do estado; e, terceiro, o caráter aglutinador da liderança exercida pelos presidentes sindicais na mobilização política dos ferroviários em favor da militância e do engajamento político.

O movimento dos trabalhadores ferroviários era bem organizado, relativamente coeso e exercia grande influência sobre a massa operária em virtude de sua tradição e do fato de muitas reuniões terem ocorrido de forma conjunta ao congregar trabalhadores de cidades e companhias distintas. O município paulista de Bauru, por exemplo, ilustra bem esse aspecto, pois havia a confluência de três importantes ferrovias na cidade: a Noroeste, a Sorocabana e a Paulista. A ação política do sindicato da Noroeste, a propósito, não influenciava apenas a mentalidade dos ferroviários bauruenses; pelo contrário, acreditava-se na ideia de uma Frente Única Operária, cujo enlace ideológico se daria através de uma série de alianças com outras cidades do interior paulista, na intenção de mobilizar diferentes camadas sociais e organizações políticas para a luta contra o governo (Brusantin, 2003, p. 49).

Em linhas gerais, a ação dos ferroviários se caracterizava por ser um movimento organizado de repúdio à política autoritária e repressiva, particularmente do primeiro governo Vargas, que atuava mediante os sindicatos sediados nas principais cidades do interior de São Paulo e que, em algumas de suas mensagens, agia como difusora da doutrina comunista/socialista entre as estações através das próprias composições ferroviárias. Enfatizamos também que a década de 1930 assinala um período de grande agitação e contestação política dos ferroviários da Paulista, embora não se encontre praticamente informações nos relatórios da diretoria da Companhia sobre movimentos de contestação promovidos pelos ferroviários. A propósito, a diretoria sequer menciona em sua documentação acerca da greve desencadeada pelos funcionários das oficinas de Jundiaí no ano de 1934.

Neste ano, um artigo do periódico $O$ Dia divulgou que o Sindicato dos Ferroviários da Paulista, na figura do seu presidente Nuncio Soares da Silva, estava organizando um movimento grevista que paralisaria as atividades de todas as seções da Companhia. Natural da cidade de Rio Claro, Nuncio Soares era considerado pela polícia como o "grande líder" do movimento sindical da Paulista. Não à toa, em 1935, ele acabou sendo demitido da ferrovia segundo a alegação de envolvimento com atividades "subversivas". No ano seguinte, em 15 de julho, ele foi condenado a seis meses de detenção por ter causado danos na rede de comunicação telefônica da ferrovia (prática comum de greve), quando da sublevação ocorrida 
Sindicalismo e trabalho ferroviário em São Paulo: a Companhia Paulista de Estradas de Ferro entre o início do século XX e sua estatização

na noite de 18 de janeiro de 1934. Nuncio Soares ficou preso até 12 de junho de 1937 e, em 1947, seu nome apareceria numa lista de filiados do PSB (São Paulo, Deops, Prontuário n. 2345).

O Sindicato dos Ferroviários da Paulista, com sede em São Carlos, também tinha grande atuação junto ao movimento operário da época. Seu tesoureiro, o português Domingos Teixeira Pinto, era tido como prestigiado agitador do movimento e principal elemento de ligação do PSB com o movimento sindical. Já José Maurano atuava como informante do sindicato na região dos arredores da cidade de Bebedouro. Também, em 1933, o maquinista da Paulista, João Soares Pinheiros, fez parte, como representante sindical, da Comissão de Reivindicação da Lei de Pensões e do Regulamento do Trabalho Ferroviário, ao lado de Jurandyr Bueno, representante dos ferroviários da Noroeste, e José Antunes de Oliveira, da São Paulo Railway (Brusantin, 2003, p. 38).

Pelo que se pode depreender dos prontuários policiais por nós arrolados, a repressão ao movimento dos ferroviários no estado de São Paulo foi se acentuando progressivamente a partir de 1932, quando o Deops confiscou um conjunto de boletins com mensagens consideradas de teor comunista no sindicato em São Carlos. Seguindo a cronologia dos fatos, em abril de 1933 a polícia política monitorou uma reunião ocorrida nesse município com os representantes dos ferroviários das principais estradas de ferro paulistas; em junho, apreendeuse um exemplar do jornal $O$ Trilho, editado pelos ferroviários, e constatou-se a realização do Congresso dos Ferroviários no qual se discutiu os planos de reivindicação e melhorias para a classe. Em outubro, uma nova reunião com o mesmo propósito se realizou em Bebedouro; em novembro, a polícia apertou o cerco à articulação política dos ferroviários ao reprimir o movimento sindical em São Carlos, Bauru e Rio Claro com a prisão preventiva de alguns dos principais líderes locais. No mês de dezembro, a polícia espionou uma reunião dos sindicatos dos ferroviários paulistas, constatando que estes planejavam um "golpe" em conjunto com a Legião Cívica 5 de Julho (São Paulo, Deops, Prontuário n. 2432).

Em 1934, o Deops elencou os nomes de cerca de vinte presos políticos envolvidos com o movimento ferroviário. Vigiados sistematicamente pelas delegacias regionais, os sindicatos e as delegações ferroviárias foram sendo paulatinamente desmobilizados como consequência do crescente controle policial. A eclosão da greve dos ferroviários da Paulista na madrugada do dia 19 de janeiro produziu a justificativa que faltava ao governo paulista para ensejar uma onda ainda mais acentuada de repressão e violência contra os trabalhadores que lutavam pela garantia e ampliação dos direitos da categoria.

Em paralelo ao caráter repressor da polícia política varguista, que perseguia sistematicamente as lideranças sindicais e parte dos trabalhadores filiados aos sindicatos oficiais e não oficiais, o mais representativo e perene legado institucional deixado pelo Estado Novo (1937-1945) foi o sistema corporativista de relações de trabalho. Seguindo a tendência mundial do período marcado pela Grande Depressão, o Estado brasileiro "formatou 
autoritariamente mecanismos de reconhecimento dos direitos e das formas de representação dos trabalhadores" (Fortes, 2007, p. 64).

Até a Constituição de 1946, os sindicatos estavam, em geral, impedidos de fazer qualquer tipo de oposição à política econômica do governo, sob o risco de terem suas cartas de reconhecimento para funcionarem suspensas. Era evidente a determinação do artigo 45, segundo o qual seria passível de cassação aquele sindicato que deixasse de satisfazer as condições de constituição e funcionamento estabelecidos na lei e/ou que se recusasse a obedecer (sic) "as normas emanadas das autoridades corporativas competentes ou às diretrizes da política econômica ditadas pelo presidente da República” (Costa, 1986, p. 56).

\section{A questão previdenciária e o impasse salarial na Paulista às vésperas de sua estatização}

De um total de 749 sindicatos oficialmente reconhecidos pelo Estado brasileiro em 1936, tal cifra se elevou para 1.669 em 1961, um aumento da ordem de 122\% (IBGE, 2007). Embora não se tratem de dados desagregados, não permitindo assim identificar se havia ou não sindicatos rurais, por exemplo, o fato é que o ritmo de criação de novos sindicatos ainda se mostrava intenso no início da década de 1960, quando a Paulista foi estatizada. Mais significativo ainda é considerarmos o nível de associativismo dos trabalhadores expresso na proporção daqueles sindicalizados em relação ao total da população economicamente ativa.

Tomando-se por base o ano de 1960, o percentual de trabalhadores sindicalizados era de 6,11\% da PEA no Brasil como um todo, índice sem dúvida muito baixo. Concentravamse os sindicalizados na região Centro-Sul do país. Em São Paulo, essa mesma proporção subia para 9,77\%. Considerando-se a inexistência de sindicatos rurais na época, podemos reduzir o universo ao contingente da PEA ligado a atividades urbanas. Em relação a este, o percentual de sindicalização paulista sobe para $14,45 \%$. São, ainda assim, índices significativamente baixos (Mattos, 2009, p. 91).

A despeito do relativo baixo índice de sindicalização dos trabalhadores brasileiros até o início dos anos 1960, importa salientarmos que havia algumas exceções quando consideramos esse índice de modo desagregado por categoria profissional. Para os casos dos estados do Rio de Janeiro e São Paulo, dois dos mais industrializados do país, três categorias apresentam taxas de sindicalização consideradas elevadas para os padrões nacionais do período aqui em foco. São elas: a classe dos bancários, dos metalúrgicos e dos ferroviários (Mattos, 2009 , p. 92$)^{6}$.

O exame da documentação produzida pelo Deops sugere que durante o período estadonovista, a atividade sindical dos ferroviários da Paulista buscou se afastar dos grupos políticos mais radicais, em especial após a constante e intensa vigilância policial sofrida entre

(6) Mattos observa também que: “[...] o sindicato dos bancários, com um índice de associação de aproximadamente $75 \%$ às vésperas do golpe militar (25.929 sócios em aproximadamente 35 mil bancários); dos ferroviários da Leopoldina, cuja marca de filiação chegava a 85\% (17 mil sócios para 20 mil trabalhadores na base), segundo depoimento do ex-presidente do sindicato, Demisthóclides Batista; e dos metalúrgicos, com um índice que atingia 50\% da categoria em 1961” (2009, p. 92). 
Sindicalismo e trabalho ferroviário em São Paulo: a Companhia Paulista de Estradas de Ferro entre o início do século XX e sua estatização

os anos 1934-36, como deixa claro o trecho abaixo de um relatório datado de 27 de fevereiro de 1939.

Sobre o "Sindicato dos Ferroviários da Companhia Paulista de Estradas de Ferro", esta Secção informa que, presentemente, nada consta contra o mesmo, com referencia a atividades políticas de caracter extremistas. Até pouco tempo atrás esteve sob severa vigilância, porquanto, foi, em outra época, um Sindicato que, com outros, motivou enérgica acção desta Delegacia em virtude de se encontraram na direção do mesmo elementos agitadores que, em 1934, de parceria com organizações extremistas, levaram a efeito uma greve que, note-se bem, assumiu um caracter de extrema violência, tão somente motivada pelos elementos pertencentes ao referido Sindicato, sendo que os mesmos foram convenientemente processados e condenados. Presentemente, como já é do conhecimento público, o Partido Comunista Brasileiro está exercendo forte pressão nos Sindicatos legalmente constituídos, no sentido de orienta-los sob sua doutrina. Vários dos mesmos já sentiram essa influencia. Quanto ao Sindicato dos Ferroviários da Companhia Paulista, nada foi observado por esta Delegacia, por enquanto, que nos autorize a informar que essa organização esteja sob a influência comunista (São Paulo, Deops, Prontuário n. 5176).

Tais informações foram prestadas pelo delegado adjunto do DEOPS, Dr. Pinto de Castro, à Secretaria da Viação diante da campanha que o sindicato dos ferroviários "pretendia fazer em prol do reajustamento dos empregados da referida estrada de ferro". O fato é que sob a presidência na Paulista de Antônio de Pádua Salles - que exerceu o cargo de 19 de março de 1936 a 27 de abril de 1949 -, a diretoria da Companhia oferecia o equivalente a meio ou, eventualmente, um mês de salário aos seus funcionários como forma de gratificação pelo trabalho realizado no decorrer de cada ano fiscal. Não obstante, em 26 março de 1945, ferroviários da Paulista e da Companhia Mogiana entraram em greve na cidade de Campinas, em particular os funcionários da Seção de Baldeação e Bagagens num total de mais de 400 trabalhadores, para reivindicar o pagamento de $\mathrm{Cr} \$ 2,50$ por hora, considerando a jornada normal de trabalho de oito horas diárias, além de duas horas livres para a realização das refeições (Deops, Prontuário n. 1066). Segundo o Sindicato dos Trabalhadores em Empresas Ferroviárias da Zona Paulista, os pleitos dos grevistas "eram justos quanto à insuficiência de salários, em face do elevado padrão da vida atual, uma vez que os mesmos não bastam para sufocar um elevado e insofismável argumento: 'a fome"” (São Paulo, Deops, Prontuário n. 1066).

Não obstante o fato dos ferroviários terem sido atendidos em suas reivindicações no episódio dessa paralização que durou cinco dias ${ }^{7}$, o presidente seguinte a Salles, Jayme Pinheiro de Ulhôa Cintra, interrompeu a política de gratificações salariais de cunho paternalista

(7) O embaixador José Carlos de Macedo Soares, representando o presidente da Paulista, e o inspetor geral Dr. Jaime Pinheiro de Ulhôa Cintra entraram em entendimento no dia lo de abril de 1945 com o sindicato da classe em relação ao "pagamento da hora de trabalho do pessoal da Baldeação e Bagagem à razão de $\mathrm{Cr} \$ 2,30$ e mais 2 horas com 25 por cento de acréscimo, fazendo ainda, espontaneamente, o aumento para todos os demais empregados horistas. "Assim, os funcionários que vinham recebendo Cr\$360,00 mensais passaram a fazer jus a um salário de $\operatorname{Cr} \$ 460,00$ e, alguns, até de Cr\$ 603,00, com a garantia do equivalente a mais 2 horas de trabalho extraordinário por dia (São Paulo, Deops, Prontuário n. 1066). 
e, em função da obrigatoriedade imposta por uma nova legislação trabalhista, instituiu as contribuições aos institutos de previdência e assistência social. Logo no seu primeiro ano de mandato, em 1950, a diretoria viu-se obrigada a repassar periodicamente determinadas cotas em dinheiro às seguintes instituições: Caixa de Aposentadoria e Pensões dos ferroviários da Paulista (depois chamada de Instituto de Aposentadoria e Pensões), Fundo Único de Previdência Social, Legião Brasileira de Assistência, Serviço Social Rural e Serviço Nacional de Aprendizagem Industrial - Senai (Companhia Paulista, Relatório, 1951, p. 15-16).

Em meados dos anos 1950, no entanto, a Paulista se deparou com uma situação de flagrante descompasso entre os planos de previdência dos trabalhadores das ferrovias estatais (de propriedade do governo de São Paulo) e seu sistema de contribuições previdenciárias. Como alternativa para remediar tal discrepância, a diretoria se comprometeu a:

Assegurar, mediante resolução da Diretoria, aos empregados cujo vencimento médio calculado na base de 12 meses que vigora atualmente ou de outra que a legislação venha a instituir - for superior ao limite máximo estabelecido para efeito de concessão de aposentadoria:

1. Aos que contarem mais de 35 anos de serviço ferroviário e mais de 65 anos de idade, uma aposentadoria complementar fixa, igual à diferença entre a concedida pela Caixa de Aposentadoria e Pensões e aquela calculada na base do vencimento médio percebido.

2. Aos que se invalidarem e contarem mais de 30 anos de serviço ferroviário, uma aposentadoria complementar fixa, correspondente à diferença entre a concedida pela Caixa de Aposentadoria e Pensões e aquela calculada na base do vencimento médio percebido.

3. Aos herdeiros do empregado (esposa, filhos menores e filhas solteiras que não provejam à própria subsistência) uma pensão correspondente a $50 \%$ da aposentadoria complementar, ordinária ou por invalidez, a que o empregado fizer jus, ou estiver percebendo.

4. Essas medidas são extensivas aos empregados que, por força de mandato eletivo e sem solução de continuidade, passarem a fazer parte da Diretoria da Companhia, calculadas na base média dos honorários e proventos do cargo que estiverem exercendo observados os prazos estabelecidos na legislação para o cálculo do vencimento médio nas aposentadorias dos empregados.

Essas medidas não terão aplicação imediata, tendo a se considerar o tempo de serviço, a idade dos empregados e, ainda, o limite máximo atual de aposentadoria dos ferroviários, estabelecido, pela legislação vigente, em Cr\$24.000,00 mensais.

Mesmo que esse limite máximo de aposentadoria venha a ser reduzido, diminuto será o número de empregados que se beneficiarão das vantagens estabelecidas, acarretando, inicialmente, despesas de pequeno vulto (Companhia Paulista, Relatório, 1955, p. 17-18).

Depreendemos do trecho citado que esse complemento no plano de aposentadoria beneficiou um número reduzido de ferroviários: os mais velhos, as vítimas de invalidez devido a acidentes de trabalho e os membros da diretoria. O fato é que a Paulista, desde 1952 e mediante acordo estabelecido na Justiça do Trabalho, manteve o nível salarial do seu pessoal 
Sindicalismo e trabalho ferroviário em São Paulo: a Companhia Paulista de Estradas de Ferro entre o início do século XX e sua estatização

equivalente ao dos ferroviários da E.F. Sorocabana. No entanto, em 1955, o governo do estado de São Paulo determinou um aumento de salário aos funcionários desta ferrovia, desfazendo, assim, a equiparação antes observada, o que forçou a Paulista a conceder novo aumento salarial, na base uniforme de Cr\$ 700 mensais (Companhia Paulista, Relatório, 1956, p. 18).

Este aumento, por sua vez, exigia uma cobertura anual estimada de Cr\$175.000.000 e, em função disso, a Paulista buscou agir de modo a barganhar revisões tarifárias junto à Contadoria Central dos Transportes e ao Departamento Nacional de Estradas de Ferro (DNEF) - órgãos estatais responsáveis pela definição das tarifas e execução da política federal de transporte. Ademais, a postura de sua diretoria sobre a questão salarial era a seguinte:

Acontece, porém, que o Governo Federal e Estadual estabeleceram, nas estradas de ferro de sua propriedade ou por eles administradas, remunerações extraordinárias, sob a forma de adicionais por tempo de serviço e salário-família, criando, assim, salários individuais não previstos em nossa legislação trabalhista. Da adoção dessa medida resultou o estabelecimento de remunerações totais superiores às pagas pela Companhia e, por isso, os seus empregados pleitearam fossem as mesmas também aqui adotadas. Como concessionária de serviços públicos, a Companhia não pode deixar de acompanhar, na medida do possível, a orientação do Estado, relativa aos salários nas ferrovias sob sua administração. E, sopesados esses motivos, se viu na contingência de aceitar essa orientação, desde que lhe fossem assegurados os necessários recursos, concedendo também aos seus empregados, em caráter provisórios, aquelas formas adicionais de remuneração (Companhia Paulista, Relatório, 1956, p. 18-19).

É notório que neste ponto a Paulista não deixou de fazer sua crítica à política salarial do governo, sem, no entanto, ressaltar o caráter público dos serviços de transporte e de conduzir a formação de um consenso junto ao Estado em torno do aumento das tarifas. Sua estratégia conseguiu, pelo menos até certo ponto, contemplar a demanda dos ferroviários por melhores vencimentos, ao mesmo tempo em que transferiu o ônus desse acréscimo aos consumidores usuários do serviço ferroviário. Concedida a autorização governamental, a Paulista aumentou todos os seus preços ao adotar o mesmo regime tarifário praticado pela E.F. Sorocabana, de propriedade do governo do estado. Desse modo, seus diretores decidiram conceder aos funcionários duas gratificações extras, uma em razão da família e outra como prêmio de frequência em proporção ao tempo de serviço efetivo prestado pelo ferroviário. Em conjunto, o total do aumento de salários e das gratificações convencionadas produziu o dispêndio de Cr\$ 303.000 .000 à Companhia em 1955 (Companhia Paulista, Relatório, 1956, p. 19).

Segundo o informe da diretoria da Paulista de agosto de 1956, entraram em vigor os novos níveis de salários mínimos estabelecidos pelo Decreto Estadual n. 39.604-A. Dos pisos salariais estabelecidos para os diversos municípios atendidos pelas linhas da Companhia, o maior era o de Campinas no valor de Cr\$3.600 para 240 horas ou 30 dias de trabalho. A Paulista prontamente adotou o reajuste exigido por lei. Em janeiro de 1957, o governo concedeu novo aumento salarial aos funcionários das ferrovias sob sua responsabilidade e os desdobramentos foram exatamente os mesmos do ano anterior: a Paulista aumentou o pagamento de salários na mesma proporção mediante mais uma elevação das tarifas 
ferroviárias. Entretanto, a diretoria alertava que: "As sensiveis reduções das safras agrícolas e a crise econômica e financeira verificadas em 1956 provocaram sensível redução dos saldos da operação ferroviária da Companhia, não havendo, assim, margem para a concessão a seus empregados de gratificação de Natal” (Companhia Paulista, Relatório, 1957, p. 20).

Nesse contexto, era evidente o crescente acúmulo de problemas econômico-financeiros que a Paulista passou a enfrentar de maneira ainda mais acintosa ao longo de toda a segunda metade da década de 1950. A pressão dos ferroviários por sucessivas elevações salariais, o crescente endividamento ocasionado pelas diversas tomadas de empréstimo (além da crise cambial da época) e as intempéries climáticas ocorridas nas zonas agrícolas do estado de São Paulo, que acarretaram sensíveis diminuições dos gêneros transportados (notadamente cereais e algodão), tudo isso contribuía para o agravamento da situação de solvência da Companhia.

Tabela 2

Companhia Paulista: principais itens das despesas de custeio, 1948-1960 (Cr\$, valores nominas)

\begin{tabular}{|c|c|c|c|c|c|c|c|}
\hline \multirow[b]{2}{*}{ Ano } & \multirow[b]{2}{*}{ Despesa total } & \multicolumn{6}{|c|}{ Principais itens da despesa } \\
\hline & & Pessoal & Pessoal/total (\%) & Combustível & Combustível/total (\%) & Materiais diversos & $\begin{array}{c}\text { Materiais diversos/ } \\
\text { total (\%) }\end{array}$ \\
\hline 1948 & 340.458 .196 & 218.689 .989 & 64,2 & 51.418 .795 & 15,1 & 63.942 .027 & 18,8 \\
\hline 1949 & 387.333 .651 & 263.557 .609 & 68 & 70.670 .723 & 18,2 & 46.878 .843 & 12,1 \\
\hline 1950 & 406.651 .463 & 271.518 .063 & 66,8 & 70.407 .617 & 17,3 & 59.463 .985 & 14,6 \\
\hline 1951 & 490.884 .487 & 322.734 .577 & 65,7 & 82.395 .559 & 16,8 & 77.132 .381 & 15,7 \\
\hline 1952 & 613.442 .698 & 399.942 .523 & 65,2 & 99.196 .604 & 16,1 & 105.947 .803 & 17,3 \\
\hline 1953 & 701.823 .111 & 491.623 .753 & 70 & 97.586 .684 & 13,9 & 105.276 .988 & 15 \\
\hline 1954 & 817.890 .086 & 576.617 .614 & 70,5 & 107.261 .144 & 13,1 & 130.247 .953 & 15,9 \\
\hline 1955 & 1.030 .845 .467 & 693.866 .727 & 67,3 & 155.388 .514 & 15 & 174.499 .415 & 16,9 \\
\hline 1956 & 1.268 .590 .625 & 895.442 .014 & 70,6 & 155.714 .448 & 12,3 & 205.891 .103 & 16,2 \\
\hline 1957 & 1.571 .016 .159 & 1.171 .120 .040 & 74,5 & 166.884 .919 & 10,6 & 225.345 .181 & 14,3 \\
\hline 1958 & 1.668 .311 .273 & 1.261 .436 .682 & 75,6 & 153.396 .405 & 9,2 & 243.829 .261 & 14,6 \\
\hline 1959 & 2.248 .999 .836 & 1.690 .095 .780 & 75,1 & 150.583 .599 & 6,7 & 391.682 .428 & 17,4 \\
\hline 1960 & 2.502 .195 .447 & 1.959 .084 .136 & 78,3 & 149.678 .754 & 6 & 378.476 .126 & 15,1 \\
\hline
\end{tabular}

Fonte: RCP (1961, p. 30).

A tabela acima evidencia que o principal componente dos gastos de custeio da Paulista era a mão de obra, já que cerca de $70 \%$ das despesas totais correspondia ao pagamento de salários, independentemente da divisão departamental. Por outro lado, gastos com materiais de diversos tipos e combustíveis participavam com $16 \%$ e $13 \%$ das despesas totais de custeio, respectivamente. Acrescentamos que, em 1958, os gastos com pessoal chegaram a atingir $3 / 4$ de toda despesa da ferrovia e, a partir de então, tal tipo de despesa nunca mais se mostrou abaixo desse patamar. Já os dispêndios com combustíveis sofreram queda a partir de 1952 (excetuando o ano de 1955), como consequência da eletrificação de alguns trechos da ferrovia.

De acordo com Cardoso, cabia às Comissões de Salários-Mínimos determinar os novos níveis salariais para cada região do país. Assim, no momento seguinte à fixação de um novo salário mínimo, começava a correr um prazo de 90 dias para que o mesmo se tornasse definitivo, pois em caso de discordância sobre o novo valor cabia recurso ao Ministério do Trabalho, Indústria e Comércio impetrado por patrões e/ou empregados. Em geral, o novo nível salarial era fixado para três anos, mas poderia ser excepcionalmente alterado se a situação econômica e financeira das regiões o exigisse, o que acontecia com certa frequência, 
principalmente ao final da década de 1950 como consequência da escalada da inflação. As correções ocorridas a partir do início dessa década conseguiam de início recompor, pelo menos em parte, o poder de compra dos trabalhadores anteriormente observado, mas, em seguida, a inflação logo deteriorava os reajustamentos dos valores salariais (2004, p. 116).

Contudo, uma nova rodada de aumento dos salários mínimos nos serviços públicos estaduais foi aprovada pelo Decreto n. 45.106-A, de 24 de dezembro de 1958. Em vista do constante clamor dos ferroviários - que, grosso modo, pleiteavam a perfeita equiparação com as remunerações oferecidas aos servidores da Sorocabana -, a Paulista se encontrou impossibilitada de atender ao conjunto de reivindicações da categoria, dado o limite de sua geração de receita. De acordo com sua diretoria, mesmo as solicitações que mereciam um exame mais cuidadoso demandavam cobertura adicional de despesas por meio de novos aumentos tarifários considerados "inconvenientes, se não de resultados negativos", frente à crescente concorrência com os transportes rodoviários. $\mathrm{O}$ fato é que estes vinham aumentando exponencialmente sua participação na matriz de transporte do país (Companhia Paulista, Relatório, 1960, p. 21).

Tabela 3

Companhia Paulista: discriminação das despesas de custeio, 1950-60 (Cr\$ de 1944)

\begin{tabular}{c|c|c|c|c|c}
\hline Ano & $\begin{array}{c}\text { Administração } \\
\text { geral }\end{array}$ & $\begin{array}{c}\text { Via permanente } \\
\text { e edificios }\end{array}$ & $\begin{array}{c}\text { Conservação do } \\
\text { material rodante }\end{array}$ & $\begin{array}{c}\text { Despesas } \\
\text { comerciais }\end{array}$ & $\begin{array}{c}\text { Tráfego e } \\
\text { tração }\end{array}$ \\
\hline 1950 & 27.577 .041 & 23.167 .482 & 28.452 .265 & 5.288 .731 & 101.000 .382 \\
1951 & 29.279 .077 & 25.778 .570 & 26.923 .314 & 5.453 .870 & 111.855 .248 \\
1952 & 30.391 .855 & 32.770 .659 & 27.257 .659 & 4.015 .926 & 115.875 .352 \\
1953 & 29.222 .977 & 31.121 .569 & 25.034 .089 & 3.664 .491 & 105.680 .588 \\
1954 & 27.251 .839 & 36.098 .104 & 25.496 .632 & 2.310 .839 & 95.520 .981 \\
1955 & 28.318 .900 & 30.989 .002 & 27.995 .900 & 2.507 .135 & 105.304 .970 \\
1956 & 27.518 .216 & 30.504 .888 & 25.601 .837 & 1.241 .530 & 107.923 .631 \\
1957 & 28.800 .975 & 34.103 .178 & 33.083 .149 & 1.142 .098 & 118.993 .053 \\
1958 & 24.119 .449 & 31.104 .711 & 30.117 .086 & 1.561 .226 & 99.413 .419 \\
1959 & 24.785 .492 & 31.962 .427 & 31.810 .271 & 2.316 .026 & 89.268 .902 \\
1960 & 23.777 .810 & 27.850 .689 & 23.832 .297 & 487.145 & 75.794 .310 \\
\hline
\end{tabular}

Fonte: RCP (1955, 1956, 1960, 1961).

A Tabela 3 busca captar o efeito real sobre as despesas de custeio da Paulista entre 1950 e $1960^{8}$. Descontado os efeitos da inflação acumulada ao longo desse período que, por sinal, alcançou níveis extremamente elevados nos dois últimos anos da série ${ }^{9}$, observamos a prevalência da divisão responsável pela realização do serviço de transporte propriamente dito, denominada "Tráfego e tração". É evidente o fato de que, a partir de 1952, o trabalho sobre o material fixo e a infraestrutura ferroviária passou a superar ligeiramente, em termos de montantes gastos, a atividade de reparo do material rodante realizado nas oficinas da

(8) Como técnica para a correção dos valores monetários, adotamos o IGP-DI como índice deflator. Tal índice de preços tem sido composto pela Fundação Getúlio Vargas desde 1944.

(9) A inflação medida pelo IGP (Índice Geral de Preços) aumentou de $24,4 \%$ a.a., em 1958, para 39,4\% e 30,5\% a.a. em 1959 e 1960, respectivamente (Giambiagi et al. 2011, Apêndice Estatístico/Tabela A1, p. 247). 
Guilherme Grandi, Ivanil Nunes

Companhia em Jundiaí e em Rio Claro. Isto se deve, provavelmente, aos projetos de modernização do aparelhamento ferroviário levados a cabo no despontar da década por meio dos empréstimos externos e internos contraídos pela Paulista ${ }^{10}$.

Gráfico 1

Cia. Paulista: participação relativa dos itens das despesas de custeio, 1950-1960 (\%)

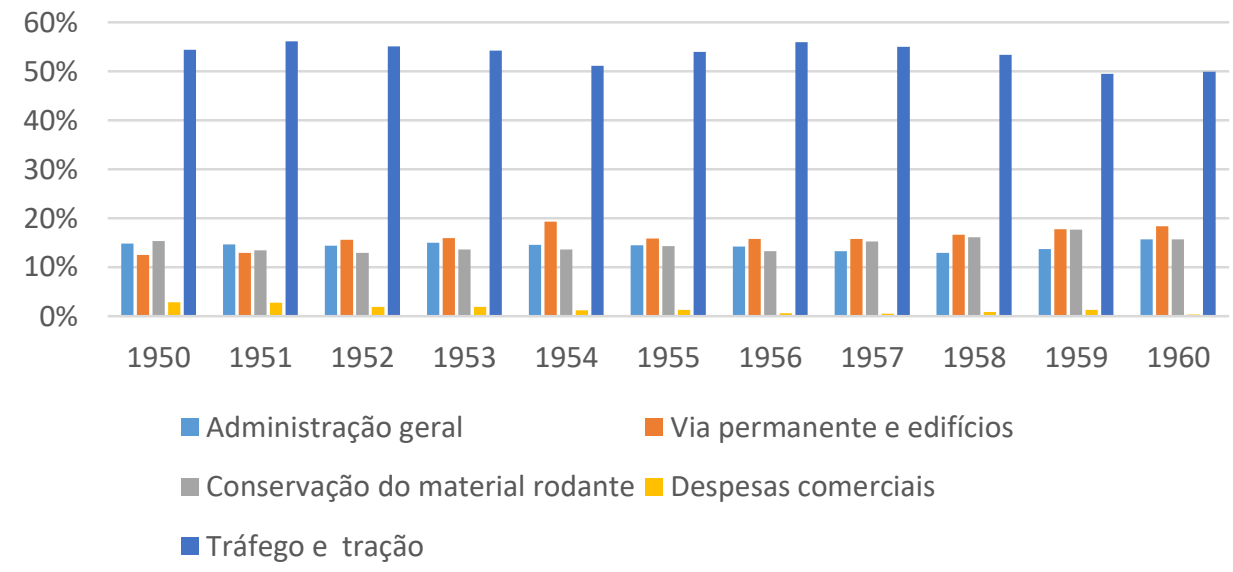

Fonte: RCP (1955; 1956; 1960; e 1961).

A imagem acima não deixa dúvidas acerca de qual divisão do trabalho ferroviário exercia um peso maior sobre o caixa da Companhia. Os resultados apresentados são perfeitamente coerentes com a natureza dos custos de operação e manutenção das estradas de ferro: os altos e, na maioria das vezes, irrecuperáveis custos (sunk costs) com material fixo e rodante. A divisão de trabalho acima referida, "Tráfego e tração", participou em média com 54\% das despesas de custeio entre 1950 e 1960. Responsável pelo reparo e manutenção de todos os equipamentos de transporte, bem como pela realização do trabalho de embarque e desembarque de bens e passageiros, tal divisão acabava exigindo somas vultosas de capital para reposição do maquinário, ao mesmo tempo em que absorvia a maior parte do contingente de ferroviários que se encontravam alocados nas oficinas e nas diversas estações ao longo das linhas férreas.

Em decorrência de um cenário econômico marcado pela alta generalizada dos preços, o Sindicato dos Ferroviários da Paulista deflagrou uma greve que durou três dias, de 14 a 16 de abril de 1959. Rapidamente, o governo do estado intercedeu com a proposta de se firmar um acordo entre as partes que imediatamente foi ratificado pelo Tribunal Regional do Trabalho. Os termos desse acordo postulavam (Companhia Paulista, Relatório, 1960, p. 21):

(10) Sobre os contratos de crédito contraídos pela Paulista no período, ver Grandi (2013, cap. III). 
Sindicalismo e trabalho ferroviário em São Paulo: a Companhia Paulista de Estradas de Ferro entre o início do século XX e sua estatização

1) Fixação do salário mínimo de Cr\$5.800 para as cinco regiões do estado de São Paulo;

2) Restabelecimento da gratificação de assiduidade de $10 \%$, incorporada ao salário, a pedido dos ferroviários em janeiro;

3) Concessão de licença prêmio, sem efeito retroativo;

4) Contribuição da Paulista para a Caixa de Aposentadoria e Pensão relativa aos prêmios concedidos aos seus funcionários, visando beneficiar suas aposentadorias.

Para que a Paulista tivesse condições de fazer jus a tais termos, o governo concedeu mais dois aumentos tarifários: um da ordem de 9,6\%, que entrou em vigor a partir de maio de 1959, e outro de 6\%, aprovado pelo Decreto Estadual n. 36.020 de 22 de dezembro de 1959 (RCP, 1960, p. 21). De fato, o pano de fundo dessa questão da equiparação dos salários pagos pela Paulista e pela Sorocabana era o crescente aumento do custo de vida dos trabalhadores no Brasil causado pelo surto inflacionário característico do final dos anos 1950. Dentre as principais reivindicações feitas pelo Sindicato estavam: aumento de $30 \%$ dos salários correspondentes a 30 dias ou 240 horas de trabalho; majoração do abono familiar de Cr\$300 para Cr\$ 600; abono de Natal de 100 horas para todos os ferroviários; incorporação do prêmio de assiduidade de $10 \%$ ao salário-base; e regulamentação da licença-prêmio (Companhia Paulista, Relatório, 1961, p. 27).

A direção da Paulista argumentava que a licença-prêmio já havia sido regulamentada e que a incorporação do prêmio de assiduidade não era factível em função das condições e consequências da incorporação do mesmo abono feita anteriormente. Não satisfeito, o Sindicato, antes mesmo de o governo do estado se manifestar a respeito do posicionamento da Companhia, informou publicamente que promoveria uma nova paralização, no dia 11 de março de 1960, caso não fosse atendido de imediato o pacote de aumento salarial e benefícios reivindicado (RCP, 1961, p. 27-28). Dito e feito, à meia noite do dia 11, inicialmente em solidariedade à greve que já estava em curso na E.F. Santos-Jundiaí (de administração do governo federal), os ferroviários da Paulista paralisaram suas atividades. A greve se estendeu até o dia 16 de março, quando o Tribunal Regional do Trabalho julgou favoravelmente ao dissídio coletivo instaurado pela Procuradoria do Trabalho. Além disso, ficou decidido que a Paulista pagaria, a partir de maio de 1960, um abono de 10\% sobre os salários vigentes, mais Cr\$ 450 referentes ao auxílio-família (Companhia Paulista, Relatório, 1961, p. 28).

Na prática, o dinamismo dos fatos seguia sempre o mesmo movimento: a cada reajuste salarial concedido aos servidores públicos pelo governo, os ferroviários da Paulista exigiam o mesmo e a Companhia, como única estratégia disponível, requeria novo aumento tarifário aos poderes competentes, de modo a subsidiar a elevação de custo sobre sua folha de pagamento. Tanto em 5 de abril como em 16 de outubro de 1960, o governo autorizou aumentos no regime tarifário da Paulista. 
Tornava-se cada vez mais clara, ao longo da década de 1950, a intenção do governo em reajustar sucessivamente o salário mínimo visando compatibilizar o valor real dos salários à realidade econômica do país, marcada pela carestia e pela compressão do poder de compra dos assalariados ${ }^{11}$. Já do ponto de vista do empresariado, os aumentos de salários acabavam gerando um efeito adverso ainda maior sobre o nível geral de preços. Com base nessa premissa, os empregadores alegavam dificuldades em absorver os custos da majoração salarial, buscavam resistir às propostas de reajustes e acabavam ameaçando o fechamento de postos de trabalho (Cardoso, 2004, p. 123).

Tabela 4

Salários médios anuais de cias. selecionadas, 1945-63 (Cr\$, valores nominais)

\begin{tabular}{l|cc|cc|cc}
\hline Anos & Sorocabana & Var. (\%) & Mogiana & Var. (\%) & Paulista & Var. (\%) \\
\hline 1945 & 7080,9 & - & 7274,1 & - & 9499,5 & - \\
1946 & 11246,4 & 58,8 & 9782,0 & 34,5 & 11503,9 & 21,1 \\
1947 & 12112,9 & 7,7 & 28599,0 & 192,4 & 12562,9 & 9,2 \\
1948 & 17082,6 & 41,0 & 10729,5 & $-62,5$ & 13077,0 & 4,1 \\
1949 & 18831,4 & 10,2 & 11348,3 & 5,8 & 15528,2 & 18,7 \\
1950 & 24553,5 & 30,4 & 12017,8 & 5,9 & 16164,9 & 4,1 \\
1951 & 25470,2 & 3,7 & 13509,8 & 12,4 & 18844,5 & 16,6 \\
1952 & 31693,1 & 24,4 & 17575,8 & 30,1 & 23008,4 & 22,1 \\
1953 & 36206,0 & 14,2 & 22668,9 & 29,0 & 29087,1 & 26,4 \\
1954 & 38250,2 & 5,6 & 30810,6 & 35,9 & 33806,9 & 16,2 \\
1955 & 49872,0 & 30,4 & 42055,0 & 36,5 & 40953,0 & 21,1 \\
1956 & 62849,2 & 26,0 & 54917,9 & 30,6 & 55986,1 & 36,7 \\
1957 & 95159,8 & 51,4 & 70655,3 & 28,7 & 74769,8 & 33,6 \\
1958 & 88188,6 & $-7,3$ & 59161,1 & $-16,3$ & 83395,3 & 11,5 \\
1959 & 132595,5 & 50,4 & 109524,0 & 85,1 & 114303,8 & 37,1 \\
1960 & 285257,0 & 115,1 & 143911,8 & 31,4 & 137643,8 & 20,4 \\
1961 & 229597,5 & $-19,5$ & 208048,7 & 44,6 & 211467,9 & 53,6 \\
1962 & 452897,6 & 97,3 & 389553,7 & 87,2 & 415444,6 & 96,5 \\
1963 & 625156,6 & 38,0 & 625053,4 & 60,5 & 822810,7 & 98,1 \\
\hline
\end{tabular}

Fonte: MVOP; Anuário Estatístico dos Transportes.

Não obstante às constantes ameaças de demissões, a pressão dos ferroviários por equiparação salarial estava longe de terminar. Em novembro de 1960, o Sindicato voltou a fazer reivindicações à Paulista, ameaçando encabeçar uma nova greve a partir da meia noite do dia 11 de novembro, caso suas exigências não fossem atendidas. Essas consistiam em abono de Natal, reajuste salarial geral de $60 \%$ (compensados os aumentos feitos a partir de janeiro de

(11) Em estudo publicado pelo Ministério do Trabalho, observa-se que até 1964 vigorou no Brasil uma política de aumento de salários reais e do número de funcionários públicos, de modo que, em 1963, os gastos com o pessoal empregado nas estradas de ferro de propriedade do Estado superavam em aproximadamente três vezes o total de suas receitas operacionais. "Nestas condições, tornava-se difícil realizar investimentos, considerando-se, ainda mais que os déficits das empresas públicas se constituíam em um dos principais componentes da expansão monetária e, consequentemente, da inflação" (Garcia; Cipollari; Carmo, 1978, p. 5). Este tipo de argumento, que relaciona o déficit do setor público com o recrudescimento da inflação e a dificuldade da política governamental em contrair a base monetária, é um dos pilares constitutivos do Plano de Ação Econômica do Governo (PAEG), adotado em 1964 pelo governo militar, além de ter sido amplamente utilizado como orientação básica das medidas que as gestões estatais das empresas de estradas de ferro deveriam adotar, visando alinhar os objetivos das empresas com os da política econômica do governo a partir do início dos anos 1960. 
Sindicalismo e trabalho ferroviário em São Paulo: a Companhia Paulista de Estradas de Ferro entre o início do século XX e sua estatização

1960) e ajuda de custo ao pessoal da equipagem, também na base de $60 \%$ (Companhia Paulista, Relatório, 1961, p. 28).

Diante da gravidade da situação, que também havia se estendido a outras ferrovias de São Paulo, a Justiça do Trabalho instaurou o dissídio coletivo ex-oficio, enquanto o governo do estado se dispôs a encontrar uma solução consensual entre as partes. O acordo logrado estabeleceu, mais uma vez mediante aumento tarifário, a concessão por parte da Paulista da gratificação de Natal, de um abono mensal aos ferroviários de 30\% - segundo o modelo adotado nas ferrovias do estado - para os salários até Cr\$ 12.000 mensais e acréscimo de Cr\$ 200 para cada Cr\$ 1.000 dos salários acima de Cr\$12.000, sendo que, para os salários já majorados em função dos novos níveis do salário mínimo, o abono corresponderia à diferença necessária para se atingir os 30\% estipulados (Companhia Paulista, Relatório, 1961, p. 29). A visão da diretoria da Paulista a respeito da conjuntura econômica, e de suas consequências à Companhia, resume bem a realidade econômica do Brasil no início dos anos sessenta.

O regime inflacionário em que vivemos há longos anos e a constante elevação do custo de vida tem agravado sensivelmente os problemas sociais, exigindo aumentos e reajustes salariais frequentes - anualmente e, às vezes, duas vezes num mesmo ano. Haja vista a fixação dos níveis de salário mínimo, que, por disposição legal, deve normalmente ser feita de $3 \mathrm{em} 3$ anos, e que nos últimos anos - por imperativos sociais - o foram em Agosto de 1956, Janeiro de 1959 e Outubro de 1960.

Em consequência dessa constante elevação de salários e do preço dos materiais, a Companhia tem sido compelida a elevar suas tarifas, no mesmo ritmo, para cobrir os encargos que daí decorrem. Assim, seus usuários vêm sendo obrigados a pagar maiores fretes e a Companhia vê agravar-se, em seu prejuízo, a concorrência rodoviária (Companhia Paulista, Relatório, 1961, p. 30).

O dia $1^{\circ}$ de junho de 1961 assinalaria a eclosão da "greve fatídica" dos ferroviários da Paulista e, consequentemente, o malogro, em definitivo, da intenção de diretores e acionistas de tentarem manter a Paulista sob a égide do capital privado. Assim, entendemos que o movimento dos trabalhadores ferroviários durante os anos 1950, combinado com a política salarial e tarifária do governo do estado de São Paulo, são fatores importantes que explicam, de modo indubitável, o processo de disputa política e econômica que culminou na estatização da última ferrovia privada do país no período anterior ao golpe militar de 1964.

\section{Considerações finais}

Buscamos argumentar neste artigo que a inflação foi o elemento que catalisou a sublevação dos ferroviários da Paulista no processo que acabou conduzindo-a para sua estatização. Ao considerarmos o contexto histórico apresentando, principalmente na última seção do texto, vimos que os ferroviários da Paulista vinham pressionando cada vez mais a diretoria da ferrovia, através do seu sindicato, ao reivindicarem sucessivos aumentos de salários, além de outras benesses equivalentes às que eram oferecidas aos funcionários das ferrovias administradas pelo governo de São Paulo. 
Não há como negarmos o protagonismo histórico dos ferroviários na trajetória de luta dos trabalhadores organizados em busca de determinados direitos e garantias constitucionais. Ao lado de portuários, têxteis, estivadores, metalúrgicos, gráficos, dentre outras categorias profissionais, os ferroviários tiveram um papel-chave na organização dos trabalhadores urbanos a partir da fundação das primeiras ligas operárias no início do século XX. A presença de trabalhadores migrantes vindos da Europa fez de São Paulo o centro da mobilização política organizada dos trabalhadores de diversos ramos industriais ao longo de toda primeira metade desse século.

Ao adentrarmos nos anos 1950, o movimento sindical já havia se irradiado do Sudeste, basicamente de São Paulo e Rio de Janeiro, ao se mostrar consolidado e atuante também em outros centros urbanos do país como Recife e Porto Alegre, para citar apenas dois exemplos. Leal é um dos pesquisadores que endossam o que estamos pontuando sem, no entanto, deixar de observar que essa década esteve marcada pela inflação como elemento estrutural do desenvolvimento econômico ou, em outros termos, como "custo do desenvolvimento". O elevado nível de preços era uma decorrência das sucessivas quedas de receita das exportações, do encarecimento dos importados (em especial, bens de capital) e dos choques de oferta dos bens destinados ao atendimento do mercado interno, fundamentalmente alimentos. Para esse autor, tal cenário era a consequência inevitável da tentativa do Estado desenvolvimentista de levar adiante a industrialização por substituição de importações. Modelo esse que funcionou até o momento em que os trabalhadores resolveram, mediante ações sindicais, reclamar mais firmemente sua parte no excedente econômico produzido (2011, p. 194).

Do ponto de vista jurídico, a Companhia Paulista foi estatizada pelo Decreto 38.548 de $1^{\circ}$ de junho de 1961, ou seja, no mesmo dia em que a greve foi deflagrada. Assim, as ações da ferrovia passaram a ser de utilidade pública para fins de desapropriação, isto é, o governo não se apropriou do patrimônio da Companhia, mas passou a administrá-la em troca do pagamento gradativo aos acionistas de um valor pré-fixado às ações, que levaram 22 anos para serem indenizados em sua totalidade.

Sobre as adversidades administrativas experimentadas pela diretoria da ferrovia ao final dos anos 1950, ponderamos que a greve de junho de 1961 expressava sintomaticamente o impasse que havia sido criado entre a Companhia e seus ferroviários. Impasse esse que se mostrou naquela conjuntura sem solução. Restava, assim, ao Estado subsidiar financeiramente a Paulista ou a greve continuaria por tempo indeterminado. Em vista de tal impasse, o governador de São Paulo à época, Carvalho Pinto, entrou em negociação com o governo federal para que fosse aprovado um subsídio de Cr\$440.000.000 à ferrovia, no qual cada governo arcaria com metade desse valor. Dado que o presidente Jânio Quadros acabou dissuadindo do acordo que, de início, ele havia consentido, Carvalho Pinto não hesitou em desapropriar as ações da Paulista, numa estratégia de mantê-la como patrimônio do estado de São Paulo frente à intenção do governo federal de incorporá-la à Rede Ferroviária Federal S.A. (RFFSA). 
Sindicalismo e trabalho ferroviário em São Paulo: a Companhia Paulista de Estradas de Ferro entre o início do século XX e sua estatização

Cabe também notarmos que mesmo antes, em abril de 1959, o presidente do Sindicato dos Trabalhadores em Empresas Ferroviárias da Zona Paulista, Harry Normanton, já havia encaminhado um documento aos acionistas da Paulista, no qual se manifestava a favor de um projeto de lei do deputado estadual Cássio Ciampolini do Partido Social Democrático (PSD), apresentado à Assembleia Legislativa, que propunha a desapropriação das vias férreas, dos equipamentos de transportes e dos prédios utilizados pela Companhia (Correio Paulistano 15/04/1959).

Discutimos na terceira seção do artigo como a atuação dos órgãos de repressão do Estado varguista perseguiu e coagiu sistematicamente à ação sindical dos ferroviários paulistas. Como resultado desse esforço contínuo da polícia política da época, constatamos que entre os anos de 1934/36, os principais líderes sindicais, que sugeriam às autoridades policiais qualquer tipo de vinculação com as organizações de esquerda, já haviam sido presos ou afastados dos sindicatos. Restaria saber quantos desses líderes sindicais e ferroviários sindicalizados foram assassinados ou continuaram suas trajetórias de lutas a margem dos sindicatos oficiais e de modo clandestino.

Por último, convém destacarmos os diversos compromissos trabalhistas que as empresas ferroviárias de São Paulo assumiram durante o período anterior à institucionalização da CLT. Antecipando-se, assim, às normas legais que seriam sancionadas bem posteriormente pelo Ministério do Trabalho, Indústria e Comércio, a Companhia Paulista, por exemplo, já havia adotado em 1917 a jornada de trabalho de seis e oito horas, além de ter sido a primeira ferrovia a pagar horas extras por serviço aos seus funcionários. Como foi salientado, a Paulista também teve uma colaboração decisiva na elaboração da lei de aposentadorias e pensões, que começou a vigorar em abril de 1923, além de ter participado ativamente do estudo que serviu de embasamento ao texto que acabou dando origem à CLT.

Assim, o conjunto de evidências históricas reunidas ao longo deste artigo é uma prova contundente da contribuição da luta sindical dos ferroviários paulistas ao aparato institucional voltado às questões trabalhistas, e que se dinamizariam, de modo mais claro, a partir dos anos 1930. Este dado, no entanto, não reduz a necessidade de que novas pesquisas possam iluminar ainda mais a compreensão sobre os aspectos positivos e negativos das relações de trabalho, encetadas a partir das sucessivas reformas experimentadas pelo Estado brasileiro no decorrer do século XX.

\section{Fontes primárias}

AVANTI! 24 maio 1907.

A TERRA Livre, 11 nov. 1906.

A VOZ do Trabalhador, 1 jun. 1909.

BRASIL, Instituto Brasileiro de Geografia e Estatística (IBGE). Estatísticas do século XX. Rio de Janeiro: IBGE, 2007. 
Guilherme Grandi, Ivanil Nunes

BRASIL. Ministério da Viação e Obras Públicas. Estatísticas das estradas de ferro do Brasil. Rio de Janeiro: Imprensa Nacional (anos diversos).

BRASIL. Ministério da Viação e Obras Públicas (MVOP). Estatísticas das Estradas de Ferro da União e das Fiscalizadas pela União Relativa ao anno de 1906. Rio de Janeiro: Typographia do Jornal do Commercio, 1908.

BRASIL. Ministério da Viação e Obras Públicas (MVOP). Estatísticas das Estradas de Ferro da União e das Fiscalizadas pela União Relativa ao anno de 1916. Rio de Janeiro: Imprensa Nacional, 1922.

CORREIO Paulistano, 15 abr. 1959.

COMPANHIA PAULISTA DE ESTRADAS DE FERRO. RCP (Relatórios da Companhia Paulista). Relatórios da Diretoria da Companhia Paulista de Vias Férreas e Fluviais apresentados à Assembleia Geral dos Acionistas. São Paulo, 1951, 1955, 1956, 1957, 1960, 1961.

SÃO PAULO. Departamento Estadual de Ordem Política e Social (DEOPS), Prontuário n. 1066 - Companhia Paulista de Estradas de Ferro.

SÃO PAULO. DEOPS. Prontuário n. 2345 - Nuncio Soares da Silva.

SÃO PAULO. DEOPS. Prontuário n. 2432. v. 1 - Ferroviários.

SÃO PAULO. DEOPS. Prontuário n. 5176 - Sindicato dos Ferroviários da Companhia Paulista de Estrada de Ferro.

\section{Referências bibliográficas}

BIONDI, L. Classe e nação: trabalhadores e socialistas italianos em São Paulo, 1890-1920. Campinas, SP: Editora da Unicamp, 2011.

BOITO JR., A. O sindicalismo de estado no Brasil: uma análise da estrutura sindical. Campinas: Ed. da Unicamp; São Paulo: Hucitec, 1991.

BRUSANTIN, B. M. Na boca do sertão: o perigo político no interior do Estado de São Paulo (1930-1945). São Paulo: Arquivo do Estado/Imprensa Oficial do Estado, 2003.

CARDOSO, H. H. P. A política salarial e os trabalhadores em Minas Gerais nos anos 50. História Econômica \& História de Empresas, v. 7, n. 2, p. 113-131, 2004.

COLLIER, R. B.; COLLIER, D. Shaping the political arena: critical junctures, the labor movement, and regime dynamics in Latin America. Notre Dame, Ind., University of Notre Dame Press, 2002.

COSTA, S. A. Estado e controle sindical no Brasil. São Paulo: T.A. Queiroz, 1986. 
Sindicalismo e trabalho ferroviário em São Paulo: a Companhia Paulista de Estradas de Ferro entre o início do século XX e sua estatização

DECCA, E. S. 1930, o silêncio dos vencidos: memória, história e revolução. 5. ed. São Paulo: Brasiliense, 1992.

FORTES, A. O Estado Novo e os trabalhadores: a construção de um corporativismo latinoamericano. Locus: Revista de História, v. 13, p. 61-86, 2007.

GARCIA, M. E.; CIPOLLARI, P.; CARMO, H. C. E. Emprego, salários e produtividade nas ferrovias brasileiras. Brasília: Ministério do Trabalho, 1978.

GIAMBIAGI, F. et al. (Org.). Economia brasileira contemporânea: 1945-2010. 2. ed. Rio de Janeiro, Elsevier/Campus, 2011.

GOMES, A. C. Burguesia e trabalho: política e legislação social no Brasil (1917-1937). 2. ed. Rio de Janeiro: 7 Letras, 2014.

GRANDI, G. Estado e capital ferroviário em São Paulo: a Companhia Paulista de Estradas de Ferro entre 1930 e 1961. São Paulo: Alameda, 2013.

GRANDI, G. The first great railway strike: rereading the early labour movement in São Paulo. International Review of Social History, v. 59, Special Issue 22, p. 161-183, 2014.

LAMOUNIER, M. L. The "labour question" in nineteenth-century Brazil: railways, export agriculture, and labour scarcity. London: London School of Economics, 2000. (Working Papers in Economic History, n. 59/00).

LAMOUNIER, M. L. Ferrovias e mercado de trabalho no Brasil do século XIX. São Paulo: Edusp, 2012.

LANNA, A. L. D. Trabalhadores das ferrovias: a Companhia Paulista de Estradas de Ferro, 1870-1920. Varia História, v. 32, n. 59, p. 505-545, 2016.

LEAL, M. A reinvenção da classe trabalhadora (1953-1964). Campinas, SP: Ed. da Unicamp, 2011.

MATTOS, M. B. Trabalhadores e sindicatos no Brasil. São Paulo: Expressão Popular, 2009.

RODRIGUES, L. M. Trabalhadores, sindicatos e industrialização. São Paulo: Brasiliense, 1974.

SILVA, M. M. F. Primeiro centenário das ferrovias brasileiras. Rio de Janeiro: IBGE, 1954.

SIMÃO, A. O sindicato na vida política do Brasil. In: SIMÃO, A. Sindicato e Estado: suas relações na formação do proletariado de São Paulo. $3^{\text {a }}$ ed. São Paulo: Hucitec, 2012.

VERSIANI, F. R. Imigrantes, trabalho qualificado e industrialização: Rio e São Paulo no início do século. Revista de Economia Política, v. 13. n. 4 (52), p. 77-96, 1993. 